PATIK : Jurnal Hukum

https://ejournal.uhn.ac.id/index.php/patik

Volume 09 Nomor 01, April 2020 Page : 40 - 50

p-issn : $2086-4434$

\title{
TINJAUAN YURIDIS ATAS TANGGUNG JAWAB PERUSAHAAN TERHADAP TENAGA KERJA YANG MENGALAMI KECELAKAAN KERJA PADA PT. NAULI SAWIT
}

\author{
Dian Pertiwi Silaban, Besty Habeahan, Rinsofat Naibaho \\ Fakultas Hukum, Universitas HKBP Nommensen \\ bestyhabeahan@uhn.ac.id,
}

\begin{abstract}
Abstrak
Tujuan dilakukan penelitian ini adalah untuk mengetahui tanggung jawab perusahaan PT. Nauli Sawit terhadap tenaga kerja yang mengalami kecelakaan kerja, dan untuk mengetahui Tindakan Pencegahan yang dilakukan PT. Nauli Sawit. Penelitian ini berlatar belakang tentang perlindungan tenaga kerja berdasarkan Undang-Undang dan penerapan jaminan perlindungan pada perusahaan yang merupakan kewajiban perusahaan. Dalam kenyataannya masih banyak perusahaan yang tidak melakukan kewajibannya dalam menerapkan perlindungan tenaga kerja. Pengumpulan data yang dilakukan dalam penelitian peneltian ini dilakukan dengan penelitian kepustakaan (library research) dan pengumpulan data dengan melakukan penelitian lapangan (field research). Hasil yang diperoleh dari tujuan penelitian, nomor satu adalah tanggung jawab perusahaan PT. Nauli Sawit terhadap tenaga kerja yang mengalami kecelakaan kerja adalah melaksanakan tanggung jawab prosedur Jaminan Sosial Tenaga Kerja, kemudian dari hasil tujuan penelitian nomor dua Tindakan Pencegahan Yang Dilakukan PT. Nauli Sawit Untuk Mencegah Tidak Terjadi Kecelakaan Kerja sebagai tindakan preventif untuk mengurangi resiko kecelakaan kerja adalah satu menyediakan fasilitas perlindungan kerja dan kedua menyediakan fasilitas peningkatan kerja.
\end{abstract}

Kata Kunci : Jaminan Sosial, Kecelakaan Kerja, Tenaga Kerja, Tanggung Jawab Perusahaan

Abstract

The objective of this study is to determine the corporate responsibility of PT. Nauli Sawit upon the workers got an occupational accident, and to find out the precautions taken by PT. Nauli Sawit to prevent work accidents from occuring for workers as a preventive measure to reduce the risk of work accidents. This research background about labor protection based on the law and the guarantee of protection to the company which is the obligation of the company. In reality there are still many companies that do not carr out their obligations in implementing labor protection. In collecting the data, this research has been done also in library research in order to get more information sources from many books and literature and also done with a field research, there interview some informant that correlating to the topic. The results obtained from the research objectives, number one is PT. Nauli Sawit oh workers who experience workplace accidents is carrying out the responsibility of labor social security procedures, then from the results of research objective number two the precautions taken by PT. Nauli Sawit to prevent work accidents from occuring as a preventive measure to reduce the risk of work accidents is one providing work protection facilities and second providing work improvement facilities.

keywords : workers, responsibility of labor social, corporate responsibility, work accident 


\section{PATIK : JURNAL HUKUM Vol : 09 No. 1, April 2020, Hal 40 - 50}

\section{Pendahuluan}

Indonesia adalah negara yang menjunjung tinggi hukum, hal ini sesuai dengan bunyi ketentuan Undang-Undang Dasar Negara Republik Indonesia dalam Pasal 1 ayat (3) Tahun 1945 yang menyatakan "Negara Indonesia adalah negara hukum". Maksud dari ketentuan sebagaimana tercantum dalam pasal tersebut adalah bahwa dalam semua segi kehidupan diatur oleh hukum tidak terkecuali dalam kehidupan ketenagakerjaan. Dalam suatu kehidupan ketenagakerjaan pasti terdapat hubungan antara pengusaha selaku pemilik / pelaku usaha dengan buruh / pekerja. Hubungan antara pengusaha dengan pekerja ini merupakan hubungan yang bersifat timbal balik yaitu, disatu sisi pengusaha membutuhkan tenaga, pikiran atau sumber daya dari pekerja untuk menjalankan usahanya, sedangkan pekerja membutuhkan uang atau penghasilan untuk dapat menjalani kehidupan sehari-hari. Hubungan antara pengusaha dan pekerja sebagaimana tersebut diatas merupakan hubungan yang bersifat saling membutuhkan atau simbiosis mutualisme, disamping pengusaha membutuhkan pekerja, pekerja juga membutuhkan pengusaha untuk kelangsungan hidupnya, jadi perlu adanya jaminan kepastian hukum hubungan antara pengusaha dengan pekerja.

Pengertian pekerja/buruh menurut Undang-Undang No 13 Tahun 2003 Tentang Ketenagakerjaan adalah setiap orang yang bekerja dengan menerima upah atau imbalan. Salah satu ketentuan dalam Undang-Undang No. 13 Tahun 2003 Tentang Ketenagakerjaan mengatur mengenai hubungan antara pengusaha dengan pekerja yaitu hubungan kerja. Hubungan kerja adalah hubungan antara pengusaha dengan pekerja / buruh berdasarkan perjanjian kerja, yang mempunyai unsur pekerjaan, upah dan perintah. Dengan demikian, hubungan kerja tersebut adalah merupakan sesuatu yang abstrak sedangkan perjanjian kerja adalah sesuatu yang konkrit, nyata, dengan adanya perjanjian kerja, maka akan lahir perikatan. Dengan perkataan lain, perikatan yang lahir karena adanya perjanjian kerja inilah yang merupakan hubungan kerja. Dalam pasal 50 Undang-Undang No. 13 Tahun 2003 Tentang Ketenagakerjaan disebutkan bahwa hubungan kerja terjadi karena adanya perjanjian kerja antara pengusaha dan pekerja / buruh. Perjanjian kerja dibuat secara tertulis atau lisan.

Perjanjian kerja yang telah disepakati oleh pekerja dengan pengusaha tidak boleh bertentangan dengan Undang-Undang yang sedang berlaku, Akibat perjanjian kerja yang sah akan melahirkan hak dan kewajiban diantara para pihak yang membuat perjanjian tersebut. Misalnya pekerja berhak atas upah, dan keselamatan kerja, dan berhak menjadi peserta Jamsostek. Sedangkan hak pengusaha berhak memperoleh hasil kerja yang dilakukan pekerja, berhak memberikan perintah kepada pekerja dan sebagainya.

Dalam unsur adanya pekerjaan resiko kecelakaan kerja tidak dapat dipungkiri oleh pekerja atau pengusaha. Resiko kecelakaan kerja adalah kejadian yang tak terduga dan tidak diharapkan terjadi. Tak terduga karena dibelakang peristiwa tersebut tidak terdapat unsur kesengajaan. Lebih-lebih dalam bentuk perencanaan. Tidak diharapkan karena kecelakaan kerja disertai dengan kerugian materil ataupun penderitaan dari yang paling ringan sampai yang paling berat, baik bagi pengusaha maupun bagi pekerja atau buruh. ${ }^{1}$

Pengertian kecelakaan kerja terdapat dalam Kepmenakertrans No. 609 Tahun 2012 Tentang Pedoman Penyelesaian Kasus Kecelakaan Kerja Dan Penyakit Akibat Kerja, Kecelakaan kerja adalah kecelakaan yang terjadi berhubung dengan hubungan kerja, demikian pula kecelakaan yang terjadi dalam perjalanan berangkat dari rumah menuju tempat kerja dan pulang ke rumah melalui jalan yang biasa atau wajar dilalui. ${ }^{2}$

\footnotetext{
${ }^{1}$ Zaeni Asyhadie, Hukum Kerja, Rajawali Pers, Jakarta, 2007, Hal.107

${ }^{2}$ Kepmenakertrans No. 609 Tahun 2012 Tentang Pedoman Penyelesaian Kasus Kecelakaan Kerja dan Penyakit Akibat Kerja
} 


\section{PATIK : JURNAL HUKUM Vol : 09 No. 1, April 2020, Hal 40 - 50}

Dalam hal terjadinya kecelakaan kerja, tenaga kerja dilindungi oleh hukum yang diatur dalam Undang-Undang No. 3 Tahun 1992 Tentang Jaminan Sosial Tenaga Kerja. Dalam pasal 1 (satu) ayat 1 (satu) berbunyi: "Jaminan Sosial Tenaga Kerja adalah suatu perlindungan bagi tenaga kerja dalam bentuk santunan berupa uang sebagai pengganti sebagian dari penghasilan yang hilang atau berkurang dan pelayanan sebagai akibat peristiwa atau keadaan yang dialami oleh tenaga kerja berupa kecelakaan kerja, sakit, hamil, bersalin, hari tua, dan meninggal dunia". ${ }^{3}$

Hal ini diperkuat dengan adanya pasal 3 ayat 2 berbunyi: setiap tenaga kerja berhak atas jaminan sosial tenaga kerja ${ }^{4}$. Kemudian diperkuat dengan adanya pasal 8 ayat 1 (satu) berbunyi "Tenaga kerja yang tetimpa kecelakaan kerja berhak menerima jaminan kecelakaan kerja: Bahwa Jaminan sosial tenaga kerja (jamsostek) adalah hak setiap pekerja dan kewajiban setiap pengusaha. Perjanjian Kerja adalah perjanjian yang dibuat antara pekerja/buruh dengan pengusaha atau pemberi kerja, hak dan kewajiban para pihak (pasal 1 angka 14 UUK). Perjanjian kerja dapat dibuat secara lisan.

Berdasarkan Pasal 1320 KUHPerdata syarat sahnya perjanjian kerja, pada umumnya yakni: Adanya kesepakatan antara para pihak, Pihak-pihak yang bersangkutan mempunyai kemampuan atau kecakapan untuk bertindak melakukan perbuatan hukum. Adanya objek pekerjaan yang diperjanjikan dan Pekerjaan yang diperjanjikan tersebut tidak bertentangan dengan ketertiban umum, kesusilaan dan peraturan perundangundangan yang berlaku.

Dalam prakteknya, walaupun ada Undang-Undang No. 3 Tahun 1992 Tentang Jaminan Sosial Tenaga Kerja yang mengatur tentang kewajiban perusahaan untuk mendaftarkan tenaga kerjanya ke dalam Program Jaminan Sosial Tenaga Kerja (pasal 4 ayat 1 (satu) UU No. 3 Tahun 1992), ternyata masih ada saja perusahaan yang tidak mendaftarkan tenaga kerjanya dalam program Jamsostek. Perusahaan yang tidak mendaftarkan tenaga kerjanya kedalam program Jamsostek sering kali lepas tangan terhadap biaya perawatan atau santunan kecelakaan kerja yang dialami oleh tenaga kerjanya, sangat jelas yang dirugikan dalam hal ini adalah tenaga kerja yang mengalami kecelakaan kerja.

PT. Nauli Sawit sebagai salah satu perusahaan yang bergerak dalam bidang pengelolaan lahan kelapa sawit yang dalam pelaksanaanya membutuhkan tenaga kerja. Pelaksanaan pekerjaanya memiliki resiko kecelakaan kerja yang tinggi sebab pada saat bekerja tenaga kerja harus menggunakan benda tajam memungkinkan pekerjanya harus berhadapan dengan egrek, dodos, kapak buah, parang. Pada saat memanen buah maupun pada saat menanam buah. Berdasarkan penjelasan latar belakang diatas, maka permasalahan yang akan dibahas adalah:

a. Bagaimana tanggung jawab PT. Nauli Sawit terhadap tenaga kerja yang mengalami kecelakaan kerja.

b. Tindakan apakah yang dilakukan oleh PT. Nauli Sawit untuk mencegah agar tidak terjadinya kecelakaan kerja.

\section{Tinjauan Pustaka}

Dalam pasal 1 No. 15 Undang-Undang No. 13 Tahun 2003 Tentang Ketenagakerjaan, Hubunga Kerja adalah hubungan antara pengusaha dengan pekerja / buruh berdasarkan perjanjian kerja, yang mempunyai unsur pekerjaan, upah berdasarkan perjanjian kerja, yang mempunyai unsur pekerjaan, upah dan perintah. Dalam pasal 50 Undang-Undang No. 13 Tahun 2003 Tentang Ketenagakerjaan disebutkan bahwa

${ }^{3}$ UU No. 3 Tahun 1992 Tentang Jaminan Sosial Tenaga Kerja Pasal 1 ayat 1 (satu) 
hubungan kerja terjadi karena adanya perjanjian kerja antara pengusaha dan pekerja / buruh. Perjanjian kerja dibuat secara tertulis atau lisan. ${ }^{5}$

Jadi, hubungan kerja adalah hubungan (hukum) antara pengusaha dengan pekerja / buruh (karyawan) berdasarkan perjanjian kerja. Dengan demikian, hubungan kerja tersebut adalah sesuatu yang abstrak, sedangkan perjanjian kerja adalah sesuatu yang konkret atau nyata. Adanya perjanjian kerja, akan ada ikatan antara pengusaha dan pekerja dengan kata lain ikatan karena adanya perjanjian kerja inilah yang merupakan hubungan kerja.

Perjanjian kerja adalah perjanjian yang dibuat antara pekerja / buruh (karyawan) dengan pengusaha atau pemberi kerja yang memenuhi syarat-syarat kerja, hak dan kewajiban para pihak (pasal 1 angka 14) Undang-Undang Ketenagakerjaan. Perjanjian kerja dapat dibuat secara lisan (pasal 52 ayat (1) Undang-Undang Ketenagakerjaan No. 13 Tahun 2003). Syarat sahnya perjanjian kerja, mengacu pada syarat sahnya perjanjian perdata pada umumnya, adalah sebagai berikut:

a. Adanya kesepakatan antara para pihak (tidak ada dwang-paksaan, dwalingpenyesatan / kekhilafan atau bedrog penipuan);

b. Pihak-pihak yang bersangkutan mempunyai kemampuan atau kecakapan untuk (bertindak) melakukan perbuatan hukum (cakap usia dan tidak dibawah perwalian /pengampuan);

c. Ada (objek) pekerjaan yang dijanjikan; dan

d. (causa) pekerjaan yang diperjanjikan tersebut tidak bertentangan dengan ketertiban umum, kesusilaan, dan peraturan perundang-undangan yang berlaku (pasal 52 ayat (1) Undang-Undang Ketenagakerjaan No. 13 Tahun 2003). ${ }^{6}$

Perjanjian kerja untuk waktu tertentu tidak dapat diadakan untuk pekerjaan yang bersifat tetap. Perjanjian kerja untuk waktu tertentu dapat diperpanjang atau diperbaharui, Perjanjian kerja waktu tertentu yang didasarkan atas jangka waktu tertentu dapat diadakan untuk paling lama 2 (dua) tahun dan hanya boleh diperpanjang 1 (satu) kali untuk jangka waktu paling lama 1 (satu) tahun, Pengusaha yang bermaksud memperpanjang perjanjian kerja waktu tertentu tersebut, paling lama 7 (tujuh) hari sebelum perjanjian kerja waktu tertentu berakhir telah memberitahukan maksudnya secara tertulis kepada pekerja/buruh yang bersangkutan, Pembaruan perjanjian kerja waktu tertentu hanya dapat diadakan setelah melebihi masa tenggang waktu 30 (tiga puluh) hari berakhirnya perjanjian kerja waktu tertentu yang lama, pembaruan perjanjian kerja waktu tertentu ini hanya boleh dilakukan 1 (satu) kali dan paling lama 2 (dua) tahun, Perjanjian kerja untuk waktu tertentu yang tidak memenuhi ketentuan sebagaimana dimaksud pada ayat (1), ayat (2), ayat (4), ayat (5), dan ayat (6) maka demi hukum menjadi perjanjian kerja waktu tidak tertentu, Halhal lain yang belum diatur dalam pasal ini akan diatur lebih lanjut dengan Keputusan Menteri. Pada keputusan menteri tenaga kerja dan transmigrasi Republik Indonesia. Perjanjian Kerja Waktu Tidak Tertentu (PKWTT) adalah perjanjian kerja yang didasarkan pada pekerjaan yang bersifat terus-menerus dan tidak bersifat pekerjaan untuk membangun jembatan dan pekerjaan untuk mengoprasikan jembatan. Pada pekerjaan membangun jembatan, ada jangka waktu untuk penyelesaian pembuatan jembatan, sedangkan pekerjaan untuk mengoprasikan jembatan, tidak ada jangka waktunya sebab jembatan tersebut digunakan oleh masyarakat sekitar setiap harinya.

Menurut Undang-Undang No. 13 Tahun 2003 Tentang Ketenagakerjaan pasal 1 ayat (2), Tenaga Kerja adalah "setiap orang yang mampu melaksanakan pekerjaan guna menghasilkan barang dan atau jasa baik untuk memenuhi kebutuhan sendiri maupun untuk

${ }^{5}$ Undang-Undang No. 13 Tahun 2003 Tentang Ketenagakerjaan Pasal 1 No. 15

${ }^{6}$ Undang-Undang No. 13 Tahun 2003 Tentang Ketenagakerjaan Pasal 52 
masyarakat"menurut pasal 1 ayat (3) UU No. 13 Tahun 2003 Tentang Ketenagakerjaan "pekerja/buruh adalah setiap orang yang bekerja dengan menerima upah atau imbalan dalam bentuk lain. ${ }^{7}$

Istilah pekerja/buruh muncul sebagai pengganti istilah buruh. Pada zaman feodal atau zaman penjajahan belanda dahulu yang dimaksudkan dengan buruh adalah orangorang pekerja kasar seperti kuli, mandor, tukang, dan lain-lain. Orang-orang ini oleh pemerintah belanda dahulu disebut dengan blue collar (berkerah biru), sedangkan orangorang yang mengerjakan pekerjaan "halus" seperti pegawai administrasi yang bisa duduk dimeja disebut dengan "white collar" (berkerah putih). Biasanya orang-orang yang termasuk golongan ini adalah para bangsawan yang bekerja di kantor dan juga orang-orang belanda dan timur asing lainnya. ${ }^{8}$

Kecelakaan kerja merupakan resiko yang dihadapi oleh tenaga kerja yang melakukan pekerjaan, karena pada umumnya kecelakaan akan mengakibatkan dua hal berikut:

1. Kematian, yaitu kecelakaan yang mengakibatkan penderitanya bisa meninggal dunia

2. Cacat atau tidak berfungsinya sebagian dari anggota tubuh tenaga kerja yang menderita kecelakaan. Cacat ini terdiri dari:

3. Cacat tetap, yaitu kecelakaan yang mengakibatkan penderitanya mengalami pembatasan atau gangguan fisik atau mental yang bersifat tetap.

4. Cacat sementara yaitu kecelakaan yang mengakibatkan penderitanya menjadi tidak mampu bekerja untuk sementara waktu. ${ }^{9}$

Jaminan sosial adalah pembayaran yang diterima pihak buruh dalam hal buruh diluar kesalahannya tidak melakukan pekerjaan. Jadi menjamin kepastian pendapatan (income security) dalam hal buruh kehilangan upahnya karena alasan diluar kehendaknya. ${ }^{10}$ Dalam pasal 1 ayat 1 UU No. 03 Tahun 1992 Tentang jaminan sosial tenaga kerja, pengertian jaminan sosial tenaga kerja dirumuskan sebagai berikut "jaminan sosial tenaga kerja adalah suatu perlindungan bagi tenaga kerja dalam bentuk santunan berupa uang sebagai pengganti sebagian dari penghasilan yang hilang atau berkurang dalam pelayanan sebagai akibat peristiwa yang dialami oleh tenaga kerja berupa kecelakaan kerja, sakit, bersalin, hari tua dan meninggal dunia. ${ }^{11}$

\section{Metode}

Penelitian ini merupakan penelitian yuridis normatif, ${ }^{12}$ yaitu suatu penelitian hukum yang dilakukan dengan cara meneliti data sekunder ${ }^{13}$ atau data yang bersifat kepustakaan yang

${ }^{7}$ UU No. 13 Tahun 2003 Tentang Ketenagakerjaan

${ }^{8}$ Zaeni Asyhadie, Op.cit, Hal 19

${ }^{9}$ Zaeni Asyhadie,Op.cit, Hal.106

${ }^{10}$ Imam Soepomo, Pengantar Hukum Perburuhan, Djambatan, Jakarta, 1974, Hal 136

${ }^{11}$ UU No. 3 Tahun 1992, Tentang Jaminan Sosial Tenaga Kerja, Pasal 1 Ayat 1

${ }^{12}$ Penelitian hukum normatif pada umumnya memiliki ciri-ciri sebagai berikut: (a) deskriptif analitis dengan pendekatan yuridis normatif; (b) tahapan penelitian adalah melalui penelitian kepustakaan, yaitu mencari data sekunder dengan menggunakan bahan hukum primer, sekunder dan tertier; (c) konsep, perspektif, teori dan paradigma yang menjadi landasan teoritikal penelitian mengacu pada kaidah hukum yang ada dan berlaku pada ajaran hukum (dari berbagai pakar hukum yang terkemuka); (d) jarang menampilkan hipotesis; (e) analisis data dilakukan secara kualitatif, artinya tanpa menggunakan angka, rumus, statistik dan matematik. Lili Rasjidi, Pengantar Metode Penelitian dan Penulisan Karya Ilmiah Hukum, Monograf atau Diktat Kuliah pada Program Doktor Ilmu Hukum Universitas Padjadjaran, Bandung, 2007, hlm. 7. Lihat juga Lili Rasjidi, Menggunakan Teori/Konsep dalam Analisis di Bidang Ilmu Hukum, 


\section{PATIK : JURNAL HUKUM Vol : 09 No. 1, April 2020, Hal 40 - 50}

diperoleh dari perpustakaan ilmiah atau sejumlah intansi terkait terhadap objek yang diteliti. Metode analisa data yang digunakan dalam penelitian ini adalah metode kualitatif, yaitu suatu analisa data berupa pengumpulan data melalui kepustakaan dan wawancara, penyajian data dalam penulisan berkaitan dengan berdasarkan penulisan yuridis normatif artinya disajikan dalam peraturan yang berlaku yang tertuang dalam Kitab Undang-Undang yang berlaku dan hasil penelitian di PT. Nauli Sawit.

\section{Pembahasan Dan Hasil}

Perwujudan kebebasan dalam masyarakat adalah hak, sedangkan konsekuensi hak adalah tanggung jawab dalam bentuk kewajiban. Oleh karena itu, dalam kehidupan seharihari dalam kebebasan selalu melekat tanggung jawab, sejalan dengan hak yang selalu melekat kewajiban. Hak adalah apa yang harus diperoleh dari pihak lain,. Sedangkan kewajiban adalah apa yang dilakukan untuk pihak lain untuk memberikan hak. ${ }^{14}$ Perwujudan hak dan kewajiban ada diatur dalam UU No 03 Tahun 1992 Tentang Jaminan Sosial Tenaga Kerja. Dalam UU tersebut diatur tentang hak dan kewajiban pengusaha dan tenaga kerja dalam bidang Jaminan Sosial Tenaga Kerja dan sebagai Badan Penyelenggara Jaminan Sosial Tenaga Kerja adalah PT. Jamsostek.

PT. Nauli Sawit sebagai salah satu perusahaan yang besar dan berpusat di Manduamas yang spesifikasi kerjanya bergerak dibidang pengelolaan lahan kelapa sawit yang dalam pelaksanaanya membutuhkan tenaga kerja. ${ }^{15}$ Pelaksanaan pekerjaannya memiliki resiko kecelakaan kerja yang tinggi sebab pada saat bekerja tenaga kerja harus menggunakan benda tajam memungkinkan pekerjanya harus berhadapan dengan egrek, dodos, kapak buah, parang pada saat memanen buah maupun pada saat menanam buah.

Tidak dapat dipungkiri dan tidak dapat diterka, tenaga kerja di PT. Nauli Sawit atau perusahaan lainnya dapat saja mengalami kecelakaan kerja baik itu karena kelalaian pekerja maupun akibat kondisi alam yang tak menentu yang bisa saja mengakibatkan kecelakaan kerja. Kondisi kecelakaan kerja tidak dapat dihindari tetapi resikonya dapat dikurangi dengan pengaturan managemen perusahaan yang bertanggung jawab. Oleh karena itu PT. Nauli Sawit telah mendaftarkan tenaga kerjanya kedalam program Jaminan Sosial Tenaga Kerja. Pendaftaran tersebut bertujuan untuk memberikan perlindungan sosial tenaga kerjanya, khususnya terjadinya kecelakaan kerja. ${ }^{16}$

Adapun hak-hak tenaga kerja yang diatur dalam UU Ketenagakerjaan adalah sebagai berikut:

1. Setiap tenaga kerja mempunyai hak dan kesempatan yang sama untuk memperoleh pekerjaan dan penghidupan yang layak tanpa membedakan jenis kelamin, suku, ras, agama, dan aliran politik sesuai dengan minat dankemampuan tenaga kerja yang bersangkutan, termasuk perlakuan yang sama terhadap penyandang cacat.

\footnotetext{
Monograf atau Diktat Kuliah pada Program Doktor Ilmu Hukum Universitas Padjadjaran, Bandung, 2007, hlm. 6-7.

13 Zulfadli Barus, "Analisis Filosofis Tentang Peta Konseptual Penelitian Hukum Normaatif dan Penelitian Hukum Sosiologis,” Jurnal Dinamika Hukum, FH Unsoed, Vol. 13 No. 2, hlm. 309, Mei 2013.

${ }^{14}$ Soekidjo Notoatmodjo, Etika dan Hukum Keselamatan, Rineka Cipta, 2010, Hal. 25

${ }^{15}$ Hasil Wawancara Dengan Bapak Marningot Tinambunan,SE, Kepala Bidang Tata Usaha PT.NAULI SAWIT Pada hari Senin, Tanggal 15 Maret 2020 PUKUL 09.00 wib

${ }^{16}$ Hasil Wawancara Dengan Bapak Marningot Tinambunan,SE, Kepala Bidang Tata Usaha PT.NAULI SAWIT Pada hari Senin, Tanggal 15 Maret 2020 PUKUL 09.00 wib
} 
PATIK : JURNAL HUKUM Vol : 09 No. 1, April 2020, Hal 40 - 50

2. Setiap tenaga kerja berhak memperoleh, meningkatkan dan mengembangkan kompetensi kerja sesuai dengan bakat, minat serta kemampuannya melalui pelatihan kerja.

3. Tenaga kerja berhak memperoleh pengakuan kompetensi kerja setelah mengikuti pelatihan kerja yang diselenggarakan pemerintah, lembaga pelatihan kerja swasta, atau pelatihan di tempat kerja.

4. Tenaga kerja yang telah mengikuti program pemagangan berhak atas pengakuan kualifikasi kompetensi kerja dari perusahaan atau lembaga sertifikasi.

5. Setiap tenaga kerja mempunyai hak dan kesempatan yang sama untuk memilih, mendapatkan, atau pindah pekerjaan dan memperoleh penghasilan yang layak di dalam atau di luar negeri.

6. Setiap tenaga kerja berhak mendapatkan waktu istirahat dan cuti, dan berhak mendapatkan kesempatan untuk melaksanakan ibadah yang diwajibkan oleh agamanya.

7. Pekerja/buruh perempuan yang dalam masa haid merasakan sakit dan memberitahukan kepada pengusaha, tidak wajib bekerja pada hari pertama dan kedua pada waktu haid.

8. Pekerja/buruh perempuan berhak memperoleh istirahat sebelum dan sesudah melahirkan, bagi pekerja yang mengalami keguguran kandungan sesuai dengan surat keterangan dokter atau bidan kandungan.

9. Setiap pekerja/buruh mempunyai hak untuk memperoleh perlindungan atas

a. keselamatan dan kesehatan kerja;

b. moral dan kesusilaan; dan

c. perlakuan yang sesuai dengan harkat dan martabat manusia serta nilai- nilai agama.

10. Setiap pekerja/buruh berhak memperoleh penghasilan yang memenuhi penghidupan yang layak bagi kemanusiaan, artinya pendapatan atau penerimaan pekerja/buruh dari hasil pekerjaanya mampu memenuhi kebutuhan hidup pekerja/buruh dan keluarganya secara wajar yang meliputi makanan dan minuman, pendidikan, kesehatan, rekreasi, dan jaminan hari tua.

11. Setiap pekerja/buruh dan keluarganya berhak memperoleh jaminan sosial tenaga kerja untuk meningkatkan kesejahteraan bagi pekerja/buruh dan keluarganya.

12. Setiap pekerja/buruh berhak membentuk dan menjadi anggota serikat pekerja/serikat buruh.

13. Pekerja/buruh dan serikat pekerja/serikat buruh berhak melakukan mogok kerja yang dilakukan secara sah, tertib dan damai apabila tidak tercapainya kesepakatan penyelesaian hubungan industrial yang disebabkan karena pengusaha tidak mau melakukan perundingan atau perundingan mengalami jalan buntu. ${ }^{17}$

Kewajiban tenaga kerja Hubungan kerja adalah hubungan antara pengusaha dengan pekerja/buruh berdasarkan perjanjian kerja. Dalam hubungan kerja pasti muncul kewajibankewajiban para pihak. Adapun kewajiban-kewajiban pekerja/buruh adalah sebagai berikut :

${ }^{17}$ Abdul Khakim, 2007, Pengantar Hukum Ketenagakerjaan Indonesia, PT. Citra Aditya Bakti, Bandung, h. 103. 


\section{PATIK : JURNAL HUKUM Vol : 09 No. 1, April 2020, Hal 40 - 50}

1. Wajib melakukan pekerjaan sesuai dengan isi perjanjian yang telah disepakati oleh para pihak. Dalam melaksanakan isi perjanjian, pekerja melakukan sendiri apa yang menjadi pekerjaannya. Akan tetapi, dengan seizin pengusaha/majikan pekerjaan tersebut dapat digantikan oleh orang lain.

2. Wajib menaati aturan dan petunjuk dari pengusaha/majikan. Aturanaturan yang wajib ditaati tersebut antara lain dituangkan dalam tata tertib perusahaan dan peraturan perusahaan. Perintah-perintah yang diberikan oleh majikan wajib ditaati pekerja sepanjang diatur dalam perjanjian kerja, undang-undang dan kebiasaan setempat.

3. Kewajiban untuk membayar ganti rugi dan denda apabila pekerja dalam melakukan pekerjaannya akibat kesengajaan atau karena kelalaiannya sehingga menimbulkan kerugian, kerusakan, kehilangan atau lain kejadian yang sifatnya tidak menguntungkan atau merugikan majikan, maka atas perbuatan tersebut pekerja wajib menanggung resiko yang timbul.

4. Kewajiban untuk bertindak sebagai pekerja yang baik. Pekerja wajib melaksanakan kewajibannya dengan baik seperti yang tercantum dalam perjanjian kerja, peraturan perusahaan, maupun dalam perjanjian kerja bersama. Selain itu, pekerja juga wajib melaksanakan apa yang seharusnya dilakukan atau tidak dilakukan menurut peraturan perundang-undangan, kepatutan, maupun kebiasaan. ${ }^{18}$

Dengan melakukan pendaftaran tenaga kerjanya ke dalam program Jaminan Sosial Tenaga Kerja ke PT. Jamsostek sebagai pihak penyelenggara, maka resiko kecelakaan kerja yang terjadi telah beralih ke PT. Jamsostek. PT. Nauli Sawit dalam menanggapi iuran Jamsostek tersebut melakukan pemungutan/pemotongan upah tiap bulan sebesar 3\% dari gaji tenaga kerjanya untuk pembayaran iuran Jamsostek tersebut ${ }^{19}$. Hal ini sesuai dengan UU No 3 Tahun 1992 Tentang Jaminan Sosial Tenaga Kerja Aangka V Pasal 22 ayat 1 (satu) yang berbunyi: "pengusaha wajib membayar iuran dan melakukan pemungutan iuran yang menjadi kewajiban tenaga kerja melalui pemotongan upah tenaga kerja serta membayarkan kepada Badan Penyelenggara dalam waktu yang ditetapkan dengan Peraturan Pemerintah". ${ }^{20}$

Dalam hal terjadinya kecelakaan kerja PT. Nauli Sawit adalah sebagai pihak yang pertama yang mengetahui kecelakaan kerja dan bertanggung jawab dalam tindakan penyelamatan pertama dari kecelakaan. Misalnya setelah terjadi kecelakaan kerja, yang dilakukan adalah membawa korban kecelakaan kerja dari lokasi kecelakaan kerja ke Rumah Sakit, Tabib, Klinik terdekat dengan lokasi kecelakaan kerja sebagai tindak lanjut penyelamatan korban dan apabila korban tersebut membutuhkan perawatan lebih intensif karena Rumah Sakit, Klinik, Tabib tersebut tidak sanggup untuk menangani korban kecelakaan kerja tersebut, dapat diminta surat rujukan untuk dipindahkan ke Rumah Sakit lain yang lebih lengkap untuk penanganan korban kecelakaan kerja yang lebih intensif dan apabila dibutuhkan korban kecelakaan kerja harus dirawat inap di Rumah Sakit.

Biaya-biaya yang dikeluarkan pada saat mengantarkan korban kecelakaan kerja tersebut ke Rumah Sakit, Tabib, klinik, dan juga biaya selama korban kecelakaan kerja tersebut dalam masa perawatan hingga sembuh didahulukan oleh PT. Nauli Sawit. Tetapi

\footnotetext{
${ }^{18}$ Lalu Husni, op. cit, h. 69.

${ }^{19}$ UU No 3 Tahun 1992 Tentang Jaminan Sosial Tenaga Kerja, Angka V, Pasal 22 Ayat 1

${ }^{20}$ Hasil Wawancara Dengan Bapak Marningot Tinambunan,SE, Kepala Bidang Tata Usaha PT.NAULI SAWIT Pada hari Senin, Tanggal 15 Maret 2020 PUKUL 09.00 wib
} 
sebelumnya pihak PT. Nauli Sawit memiliki tanggung jawab melaksanakan prosedur pelaksanaan Jaminan Sosial Tenaga Kerja yaitu:

1. PT. Nauli Sawit melaporkan kecelakaan kerja yang menimpa tenaga kerjanya kepada Kantor Departemen Tenaga Kerja dan Badan Penyelenggaraan dalam waktu tidak lebih dari 2 kali 24 jam

2. PT. Nauli Sawit melaporkan kepada Kantor Departemen Tenaga Kerja dan Badan Penyelenggara dalam waktu tidak lebih 2 kali 24 jam setelah tenaga kerjanya yang tertimpa kecelakaan dinyatakan sembuh, cacat atau meninggal dunia oleh dokter yang merawatnya.

3. PT. Nauli Sawit mengurus hak tenaga kerjanya yang tertimpa kecelakaan kerja kepada Badan Penyelenggara sampai memperoleh hak-haknya ${ }^{21}$

Tindakan preventif adalah suatu tindakan atau upaya pencegahan dari suatu pihak yang melaksanakan Disediakan kewajiban sebagai tanggung jawab atau sesuatu yang diperbuat dan dilaksanakan sebelum terjadinya suatu resiko. Dalam hal apabila terjadinya kecelakaan kerja, resiko kerugian yang dialami oleh pengusaha dan tenaga kerja tidak dapat dihindari. Maka PT. Nauli Sawit sebagai salah satu perusahaan yang besar dan bergerak dalam bidang pengelohan lahan kelapa sawit, menerapkan sistem kerja yang aman bagi tenaga kerjanya. Sistem kerja yang aman yang diterapkan oleh PT. Nauli Sawit terhadap tenaga kerjanya dilakukan dengan memperhitungkan potensi bahaya-bahaya, menerapkan perlindungan fisik dan sosial bagi tenaga kerjanya sebagai tindakan preventif agar tidak terjadi tindakan ini sesuai dengan UU No 1 Tahun 1970 tentang kesehatan dan keselamatan kerja pada pasal 9 ayat 1 (satu) yang berbunyi : "pengurus diwajibkan menunjukkan dan menjelaskan pada tiap tenaga kerja baru tentang:

a. Kondisi-kondisi dan bahaya-bahaya serta apa yang dapat timbul dalam tempat kerjanya

b. Semua pengamanan dan alat-alat perlindungan yang diharuskan dalam semua tempat kerjanya

c. Alat-alat perlindungan diri bagi tenaga kerja yang bersangkutan

d. Cara-cara dan sikap yang aman dalam melaksanakan pekerjaannya. ${ }^{22}$

PT. Nauli Sawit mewujudkan cara kerja yang aman dalam $:^{23}$

1. Menyediakan Alat Pelindung Diri

Adalah suatu kewajiban bagi persuhaan untuk menyediakan Alat Pelindung Diri dalam melaksanakan pekerjaannya dilapangan. PT. NAULI SAWIT yang ruang lingkup pekerjaannya dalam merawat lahan kelapa sawit, menanam buah yang baru, membersihkan batang kelapa sawit, memupuk batang kelapa sawit. maka mewajibkan para pekerjanya untuk memakai Alat Pelindung Diri antara lain :

a. Helm : Berfungsi sebagai pelindung kepala dari benda yang bisa mengenai langsung dari atas

b. Sepatu karet (sepatu boot) : Berfungsi sebagai alat pelindung kaki dari bahaya, biasanya berupa paku atau benda tajam

c. Sarung tangan : Berfungsi sebagai alat pelindung tangan apabila bekerja dibagian pemotongan kayu atau besi maupun pemotongan rumput lahan maupun pada batang kelapa sawit

\footnotetext{
${ }^{21}$ Hasil Wawancara Dengan Bapak Marningot Tinambunan,SE, Kepala Bidang Tata Usaha PT.NAULI SAWIT Pada hari Senin, Tanggal 15 Maret 2020 PUKUL 09.00 wib

${ }^{22}$ UU No 1 Tahun 1970 Tentang Kesehatan dan Keselamatan Kerja pasal 9 ayat 1 (satu)

${ }^{23}$ Hasil Wawancara Dengan Bapak Marningot Tinambunan,SE, Kepala Bidang Tata Usaha PT.NAULI SAWIT Pada hari Senin, Tanggal 15 Maret 2020 PUKUL 09.00 wib
} 


\section{PATIK : JURNAL HUKUM Vol : 09 No. 1, April 2020, Hal 40 - 50}

d. Kaca mata : Berfungsi sebagai alat pelindung mata, misalnya debu, percikan api serta benda-benda lainnya yang bisa masuk kedalam mata

e. Masker :Berfungsi sebagai pelindung mulut dan hidung agar terhindar dari debu, ketika sedang bekerja maupun sedang melintas disekitaran kebun kelapa sawit

2. Memberikan Pelatihan dan Pengarahan Kerja

Fasilitas peningkatan kerja yang dilaksanakan oleh PT. NAULI SAWIT berupa bentuk pendekatan atau sosialisasi terhadap tenaga kerjanya, terwujud dalam :

a. Memberikan pelatihan kerja

Pelatihan kerja atau training diterapkan oleh perusahaan kepada setiap tenaga kerja yang harus direkrut oleh perusahaan. Tindakan ini bertujuan agar setiap tenaga kerja yang telah dilatih dapat menguasai lapangan kerja yang digelutinya.

Dalam pasal 1 ayat 9 (sembilan) UU No 3 Tahun 2003 Tentang Ketenagakerjaan Pelatihan kerja Pelatihan kerja adalah keseluruhan kegiatan untuk memberi, memperoleh, meningkatkan, serta mengembangkan kompetensi kerja, produktivitas, disiplin, sikap, dan etos kerja pada tingkat keterampilan dan keahlian tertentu sesuai dengan jenjang dan kualifikasi jabatan atau pekerjaan. ${ }^{24}$

Dalam pasal 9 ayat 1 (satu) UU No 3 Tahun 2003 Tentang Ketenagakerjaan Pelatihan kerja diselenggarakan dan diarahkan untuk membekali, meningkatkan, dan mengembangkan kompetensi kerja guna meningkatkan kemampuan, produktivitas, dan kesejahteraan ${ }^{25}$

b. Memberikan Pengarahan (Briefing)

Sebelum melakukan pekerjaan dilapangan perusahaan diwakili dengan tenaga kerja senior atau disebut dengan Team Leader setiap sub divisi kerja memiliki Team Leader sebagai pengawas dan pengarah kerja bagi pekerja dilapangan. Sebelum melaksanakan kerja Team Leader memiliki tugas antara lain :

1. Memastikan tenaga kerja yang dilapangan siap untuk bekerja dan berlatih.

2. Memberikan pengarahan atas kerja yang akan hendak dilakuakn kepada para pekerja.

3. Memastikan peralatan yang akan digunakan para tenaga kerja

4. Memberhentikan pekerjaan apabila kondisi alam tidak memungkinkan seperti hujan, angin kencang dan lain lain.

5. Konsultasi

Demi menjaga keserasian kerja antara tenaga kerja dan perusahaan. PT. Nauli Sawit terbuka dalam mengatasi keluhan-keluhan para pekerja apabila ada kekurangankekurangan fasilitas-fasilitas yang disediakan oleh perusahaan, selama itu bertujuan untuk kepentingan perusahaan.

\footnotetext{
${ }^{24}$ UU No 13 Tahun 2003 Tentang Ketenagakerjaan pasal 1 ayat 9

${ }^{25}$ UU No 13 Tahun 2003 Tentang Ketenagakerjaan pasal 9
} 


\section{Kesimpulan Dan Saran}

Tanggung jawab PT. Nauli Sawit antara lain adalah PT. Nauli Sawit melaporkan kecelakaan kerja yang menimpa tenaga kerjanya kepada Kantor Departemen Tenaga Kerja dan Badan Penyelenggaraan dalam waktu tidak lebih dari 2 kali 24 jam. PT. Nauli Sawit melaporkan kepada Departemen Tenaga Kerja dan Badan Penyelenggara dalam waktu tidak lebih dari 2 kali 24 jam setelah tenaga kerjanya yang tertimpa kecelakaan oleh dokter yang merawatnya dinyatakan sembuh, cacat atau meninggal dunia. PT. Nauli Sawit mengurus hak tenaga kerjanya yang tertimpa kecelakaan kerja kepada Badan Penyelenggara sampai memperoleh hak-haknya.

Dalam Undang-Undang No 13 Tahun 2003 Tentang Ketenagakerjaan perlu di lengkapi dengan pengaturan mengenai kecelakaan kerja yang dialami oleh tenaga kerja. Pekerja harus lebih bijak dan lebih memahami serta bertanggung jawab akan hak-hak dan kewajibannya sebagai pekerja begitu juga dengan pengusaha, agar terjalin hubungan pengusaha dan pekerja yang lebih harmonis.

\section{DAFTAR PUSTAKA}

\section{Buku}

Zainal Asikin, Agusfian Wahad, Lalu Husni \& Zaeni Asyhadie. Dasar-Dasar Hukum Perburuhan. Jakarta : Rajawali Pers. 2010.

Zaeni Asyhadie, Hukum Kerja. Jakarta : Rajawali Pers. 2007.

Adrian Sutedi, Hukum Perburuhan. Jakarta : Sinar Grafika 2009.

Djumialdji, Perjanjian Kerja. Jakarta : Sinar Grafika. 2010.

Jhon Ridley, Kesehatan dan Keselamatan Kerja. Jakarta : Erlangga. 2008

Soepomo Imam, Pengantar Hukum Perburuhan. Jakarta : Djambtan. 1974.

Khakim Abdul, Pengantar Hukum Ketenagakerjaan Indonesia, PT. Citra Aditya Bakti, Bandung. 2007

Notoatmodjo Soekidjo, Etika dan Hukum Kesehatan. Jakarta : Rineka Cipta. 2010.

\section{Peraturan Perundang-Undangan}

UU No 3 Tahun 1992 Tentang Jaminan Sosial Tenaga Kerja

KepmenaKertrans No 609 Tahun 2012 Tentang Pedoman Penyelesaian Kasus Kecelakaan Kerja dan Penyakit Akibat Kerja

UU No 13 Tahun 2003 Tentang Ketenagakerjaan

UU No 1 Tahun 1970 Tentang Keselamatan dan Kesehatan Kerja 